\title{
Neighbourhood Policing and Social Cleansing of Crime in Oke-Ogun Area of Oyo State, Nigeria
}

\author{
IGE James Olateju $\quad{ }^{*}$ ADIGUN Folasade O ABOLADE Olajoke \\ Department of Urban and Regional Planning, Ladoke Akintola University of Technology, Faculty of \\ Environmental Sciences, Ogbomoso, Oyo State, Nigeria \\ *Corresponding Author
}

\begin{abstract}
The paper assessed neighbourhood policing and social cleansing of crime in Oke-Ogun area of Oyo State with a view to examining spatial variation in response to crime in the area. Both primary and secondary data were employed. The total households of urban and rural settlements as identified in Oke-Ogun area of Oyo State were 44,421 and 175,568 respectively The sample frame constituted all households in the study area, and five out of 1000 of all the 219,989 total households which approximately amount to 1100 households constituted the sample size, Random sampling was employed in hierarchical selection of $5 \%$ of the total households in each settlement type, and a total number of 1100 copies of questionnaires were randomly administered Descriptive statistics such as percentage and Chi-Square were used to present summary of findings. Findings revealed that higher order security consciousness was displayed in urban area with an insubstantial proportion of households surveyed (13.2\%) having no organisation responsible for security in their neighbourhood compared with $22.4 \%$ in the rural settlements. At aggregation level, $52 \%$ of all respondents in Oke-Ogun agreed with the adequacy of policing out of which $13.6 \%$ said that the policing was very adequate and $38.4 \%$ said that it was adequate while $48 \%$ of all respondents were at variance with the adequacy of policing. The households (49.0\%) in the rural areas were cynical about adequacy of policing, while out of $49.0 \%, 28.9 \%$ said that policing was inadequate and $20.1 \%$ said that policing was very inadequate. The chi-square performed across settlement types at $(\mathrm{P}<0.05)$ indicates that the difference in adequacy of policing was significant. The implication of this is that there is a significant difference between perception of adequacy of policing by households and the settlement types in Oke-Ogun. Households also held view that Police in Oke-Ogun did not give a prompt response expected in situations of distress call. Response to unwillingness to give prompt response to distress call by Police was on top gear in rural settlements. About $39 \%$ of all respondents in rural areas said that Police gave prompt response needed to distress call compared to $41.7 \%$ in urban areas of Oke-Ogun. For social cleansing job provision for the unemployed was ranked first by the residents among alternatives for keeping neighbourhood safe, followed by imposition of fine on offender. Jailing of offender was ranked third and equip vigilant groups was ranked fourth Improved infrastructure was ranked fifth among several options. The chi-square analysis performed $(\mathrm{P}<0.05)$ indicated that the difference in households' preference for means of keeping neighbourhood safe across settlement type was significant. The study concluded that response to crime in the area varied spatially.
\end{abstract}

Keywords: Crime, Neighbourhood, Policing, Social cleansing

DOI: $10.7176 / \mathrm{JCSD} / 51-06$

Publication date:September $30^{\text {th }} 2019$

\section{Introduction}

Crime is a global cankerworm and one of the most notable threats to rural liveability and urban development. In Nigeria, crime has all day long become a hydra-headed social monster pervading every dimension of human survival and stable life style. One is reminded of insecurity everywhere one goes in Nigeria. It is not just the window guards, burglar-proofs, fortified gates, security ramparts, sky rocketing defensive walls and the day by day news of bolder and more sophisticated crimes that indicate rampant menace, but the increased growth of troop movements in the neighbourhoods and the presence, day and night, of law enforcement agents and other armed guards patrolling the streets, highways and borders.

Crime, as Omisakin (1998) expressed, "is a social menace, an undeniable stigma to national image and a significant source of threat to people's safety and wellbeing". Increasingly, people daily depend on the protection of vigilante. Private security agents are intensively hired by organisations and individuals who can afford to pay for a multitude of motives. These motives include deep-seated fears that crime will infringe on safe neighbourhoods, which are largely due to the perceived increasing intricacy of the society, and the reality of the finiteness and limitations of government resources that could be put at the disposal of effective neighbourhood policing.

Neighbourhood policing is a philosophical strategy that are based on the notion that community interaction and support can help control crime and reduce fear (Adams, 2001). Friedman (1995) sees neighbourhood policing as a strategy whereby community members help to identity suspects, detain offenders, bring problems to the attention of Police, or otherwise target the social problems which give rise to a crime problem in the first place. Neighbourhood policing has of course taken many forms and achieved varying results (Greene and 
Mastrofski, 1988). Common characteristics of "successful" neighbourhood policing initiatives have included: efforts to understand the causes of crime related problems, analyzing patterns of problems ("hot spots"), and responding creatively to these problems through multiple means and coordination with other agencies (Lavrakas, 1995; Rosenbaum, 1987; Skogan and Hartnett, 1997; Wilson and Kelling, 1989).

Social crime prevention is a relatively new approach of crime prevention based on the premise that there is a well-established body of research that can identify factors that contribute to crime. It considers punishment to be no longer the sole or the best means of controlling crime. Instead, the concept of social crime prevention involves the rational systematization of goal-directed preventive and social control measures within an active 'social policy which aims at the protection of society by protecting the offender as well' (Odekunle, 1982). Social crime prevention in the words of Shaftoe (2002) consists of "an interlocking series of interventions that enable people to lead a life where they do not have the inclination, motivation or need to offend against others, whether for expressive or acquisitive reasons".

This approach has been suggested by various authors (Aguda, 1994; Obateru, 1994; Odekunle 1982). For instance, Odekunle (1982) emphasized the urgent necessity to institute a comprehensive national research programme on crime and criminals, crime preventions and control and the treatment of offenders to provide the data to tackle the crime problem. Aguda (1994) recommended social restructuring - total restructuring of the national economy so as to provide equal access to basic necessities of life such as food, shelter, clothing, employment. In the literal sense of the world the recommendation of Aguda is like chasing the wind and can be said to be practically unachievable to provide optimal access, let alone equal access especially in a developing country like Nigeria that runs itself like a pool betting house where winners take all and the poor majority gnash their teeth.

Oke-Ogun area is a supra-urban area, and any meaningful policy targeted at curtailing crime must understand that crime is a product of inadequacies and malfunctions in the structure of rural and urban systems. Crime is fundamentally a surface expression of social injustice and or economic inequalities which lie deeply embedded in the administration of justice and distribution of wealth in the societal systems. Few urban dwellers have unrestricted access to basic amenities, let alone rural dwellers. The minority few use their ill-gotten wealth to establish institutionalising extravaganza and squander-mania and therefore suppress, oppress and repress the majority that wallow in abject poverty and languish for wants. These engender the poor masses to be involved in criminal activities.

Crime does not occur only in urban neighbourhood. It occurs whenever and wherever there is an opportunity. Neighbourhood policing and social cleansing of crime by and large are a spatial affair and they remain a bilateral action on the part of the Police and community if we are serious in ameliorating crime effectively. It is, however, better that the interpretation and comparison must of necessity be done within the context of supra urban spatial scales for advancing our understanding of the Police and community function in crime control for planning and management security operations in the society. The study, therefore, seeks to provide analytical information on the neighbourhood policing and social cleansing of crime occurrence in OkeOgun area of Oyo State.

\section{Materials and Method \\ The Study Area}

The study area is Oke-Ogun area in Oyo State. Oke-Ogun area is the north-western region of Oyo State, and is made up of rural communities and large rural centres (small towns) located in the northern and north-western parts of Oyo State, Nigeria. Geographically, Oke-Ogun approximately stretches between latitudes $07^{\circ} 28^{\prime}$ and $08^{\circ} 38^{\prime}$ North and longitudes $03^{\circ} 02^{\prime}$ and $04^{\circ} 44^{\prime}$ East (Figure 1). Oke-Ogun shares boundary with Kwara State in the North, in the South by Ogun State, Ibarapa North and Ibarapa East local government areas; in the East by Atiba and Oyo West local government areas, and in the West by Republic of Benin. Oke-Ogun area is a borderland consisting of ten local government areas. The ten LGAs are districted into three zones, namely; Border zone: This comprises Saki West, Atisbo and Iwajowa local government areas. The local government areas within this zone share boundary with the Republic of Benin

(i) Near border zone: This comprises Saki East, Itesiwaju, Kajola and Iseyin local government areas. These local government areas share boundary with the local government areas sharing boundary with the Republic of Benin. This implies that they are indirectly connected to the border.

(ii) Far border zone: It comprises Orelope, Olorunsogo and Irepo local government areas. These local government areas share boundary with Kwara State which shares boundary with the Republic of Benin. Also, these local government areas are indirectly connected to the border. The people of Oke-Ogun are mostly Yoruba. The regional accent of Oke-Ogun is called "Onko". Some ethnic groups like Ibaruba, Filani, Aketepe, and foreigners from Republic of Benin and Togo are found practising agriculture in the area 


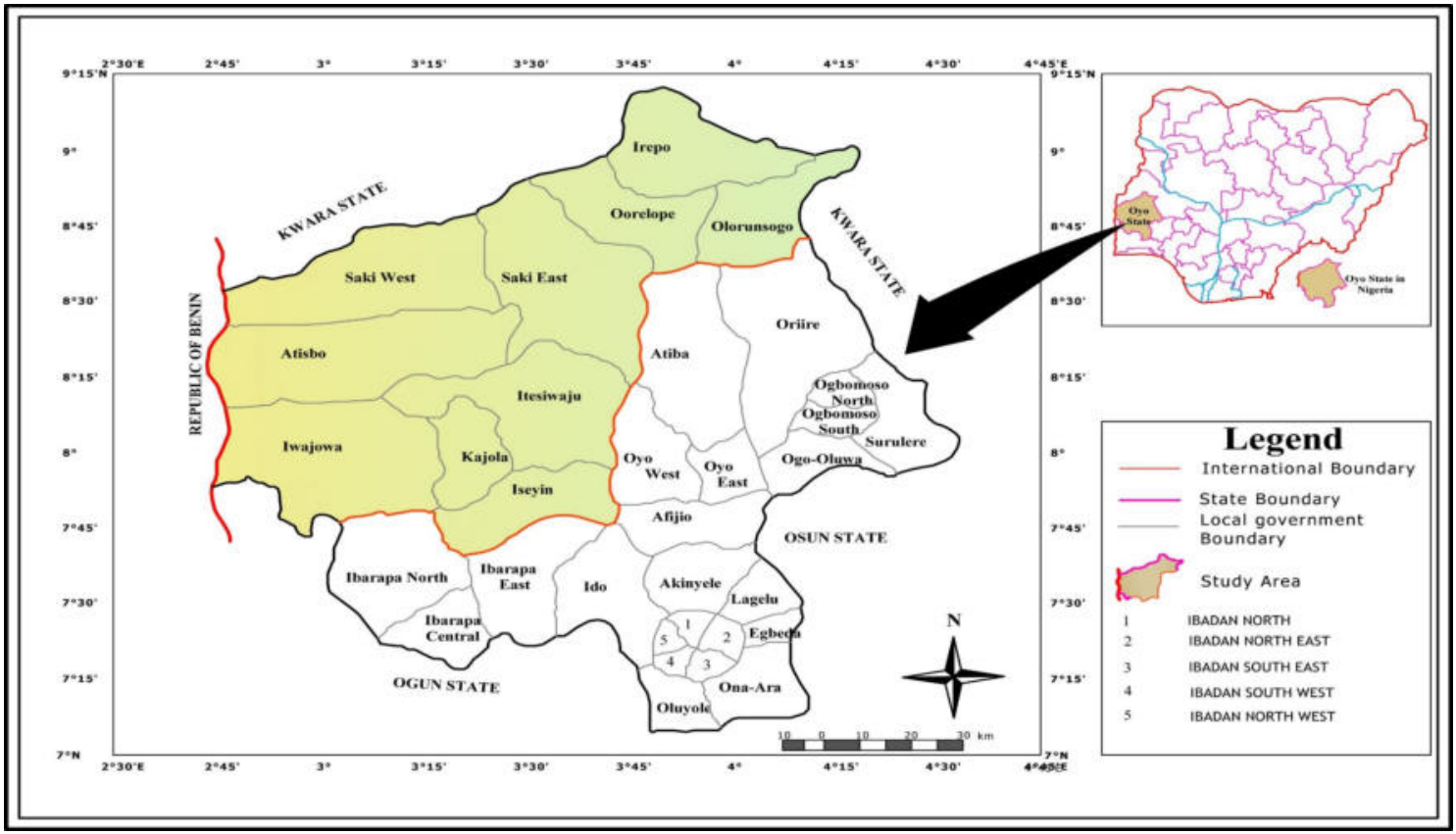

Figure 1: Oke-Ogun Area, Oyo State

\section{Data Collection and Analysis}

Data for this study were obtained from both primary and secondary sources. The data from primary sources were obtained through questionnaire, direct observation and oral interview. Questionnaire was used to obtain information on form of preventive social measures put in place in the residence as means of making neighbourhood crime free. In-depth interview was conducted on selected landlord and tenant, opinion leaders and security agents who lived in the settlement for not less than two years to complement the direct observation and questionnaire administration. Secondary data for this study included published materials, population reports and data from National Population Commission. In addition, digitized map of Oke-Ogun was obtained from the GIS laboratory of the Department of Urban and Regional Planning, Ladoke Akintola University of Technology, Ogbomoso.

All households in Oke-Ogun constituted the sample frame. Total Population and households of Oke-Ogun as extracted from 1991 National Population Census were 663,363 and 118,784 respectively. The projected population from 1991 to 2013 using growth rate of $2.8 \%$ and total households of Oke-Ogun as obtained from National Population Commission (NPC) were 1,228,548 and 219,987 respectively The total households of urban and rural settlements as identified in Oke-Ogun area of Oyo State were 44,421 and 175,566 respectively. Based on this population and household size, a certain proportion was used for the sample survey. To arrive at the sample size, sampling ratio of $0.5 \%$ of the total households was used and this constituted $0.9 \%$ of the total population in Oke-Ogun. The decision for the choices of $0.5 \%$ of all household was premised on assertion of Neuman (1994) that larger population permits smaller sampling ratio for equally good samples. Neumann's argument is that, as population size grows, the returns in accuracy for sample size shrinks. Also, Adigun (2012) reported that Singleton et al, (1989) suggested 0.05 percent as a good proportion for sample survey of large population. The sample frame constituted all households in the study area, and five out of 1000 of all the 219,989 total households which approximately amount to 1100 households constituted the sample size, In all, $5 \%$ of the total households were sampled and a total number of 1100 copies of questionnaires were administered to matured residents from 1100 randomly selected households, and a multi-stage sampling procedure was used to collect primary data through questionnaire administration.

In the first stage, settlements in the study area were stratified into two settlement types; rural and urban settlements in each of the 10 Local Government Areas (LGAs) in Oke-Ogun area of Oyo State, based on population of 20,000 persons and above for urban and less than 20,000 persons for rural settlements.

In the second stage, five per thousand $(5 \%)$ of total households in every local government area was considered. Then, a total of 5 settlements were purposively selected in each of the 10 local government areas, using a ratio of 1(urban): 4 (rural), based on settlement hierarchical selection model, (i.e., the ratio is based on the premise of average population distribution pattern among settlements). Then, one urban and four rural settlements were randomly chosen. Copies of the questionnaire were, therefore, administered to five out of every 
1000 of total households in urban and rural settlements of all the 10 LGAs in Oke-Ogun area.

In the third stage, five out of 1000 of all the 219,989 total households which approximately amount to 1100 households constitute the sample size. The total number of questionnaires administered in all 10 local government areas selected was therefore 1100. The numbers given to housing units for enumeration area demarcation for 2006 population census by National Population Commission, and a good proportion of newly constructed buildings that were outnumbered were updated, and both compiled for the selected settlement types (urban and rural) in each local government area of Oke-Ogun. From the compiled lists, required housing units were randomly selected in each of the selected settlement types. One of all persons aged 18 years and above was purposively interviewed in each selected household. Notwithstanding, children were also given the privilege of responding to the oral questions. There was, however, exceptional cases like multi-household buildings (more than one household occupying only one building): The household with longest stay in the housing unit was selected. In a multi-building single household (a single household occupying more than one building). This is a common feature of the traditional Yoruba settlements as a result of the polygamous and extended nature of Yoruba families. If two or more housing units randomly selected were of multi-building single household, only one housing unit was used while others were skipped. In this case, only one questionnaire was used just like any other household, while the remaining questionnaires were used for the nearest unselected housing unit(s) from a compiled list of housing units for the particular settlement under investigation. It is equally noteworthy to mention that there were some cases where housing units selected were empty (either unoccupied or households not at home) such housings units were skipped to the nearest unselected housing units.

Method of data analysis for data collected were mainly descriptive. Descriptive statistics were appropriately used in the analysis of results to present certain discussions and to depict vividly a summary description of the various responses for a sample drawn from a population of households. Chi-Square was used to determine level of significant difference between some elements of defence in the households and community.

\section{Results and Discussion \\ Social Cleansing \\ Treatment Metted to Offender}

Punishment is a Criminal Justice Approach in crime control, and therefore involves the entire array of government institutions that function as the instrument of a society in enforcing the standard of conduct needed for the protection, safety and freedom of individual citizens, and for the maintenance of order by detecting, apprehending, prosecuting, adjudicating and sanctioning the deviants. There were varied and various ways of treating offenders caught in Oke-Ogun. Of all respondents, $54.0 \%$ in Oke-Ogun said that the offenders caught in the act were handed over to Police, $20.1 \%$ said that offenders were given public disgrace whereby offenders would be given special dresses already made to wear and danced round the town or village. This was very common in the rural settlements in Oke-Ogun. Spontaneous forms of social cleansing that violates human rights have also appeared in the study area as a result of cynical attitudes of households to Police protection. (Table 1). What might be termed "jungle or rough justice", where individuals or groups take the law into their own hands, is less selective but no less inhuman than "social cleansing". This is also something that governments ignore or cannot control. Its victims are alleged criminal more often than not criminal caught in the act were lynched by the mob. Lynching was a bit more pronounced in urban settlement than rural settlement (Table 1), and it was a very rare method of punishing offender in the rural settlements. Criminals caught in the act were immediately put to death without trials by an angry mob. This was borne out of residents' speculation which was very difficult to divorce from the truth that a long process in the administration of justice and its attendant perversion could set the criminal free. This shows that the value and worth of Police force is best determined by the degree of confidence and the amount of cooperation Police enjoys from average citizens

Table 1 Treatment Melted to Offender

\begin{tabular}{|c|c|c|c|c|c|c|}
\hline \multirow{3}{*}{ Functionality } & \multicolumn{5}{|c|}{ Settlement } & \\
\hline & \multicolumn{2}{|c|}{ Rural } & \multicolumn{2}{|c|}{ Urban } & \multicolumn{2}{|l|}{ Total } \\
\hline & Freq & $\%$ & Freg & $\%$ & Freq & $\%$ \\
\hline Handed over to Police & 293 & 48.7 & 112 & 75.7 & 405 & 54.0 \\
\hline Lynched & 27 & 4.5 & 16 & 10.8 & 43 & 5.7 \\
\hline Handed over to Neighbourhood head & 75 & 12.5 & 12 & 8.1 & 87 & 11.6 \\
\hline Fine/Isolated & 61 & 10.1 & 3 & 2.0 & 64 & 8.5 \\
\hline Public disgrace & 146 & 24.3 & 5 & 3.4 & 151 & 20.1 \\
\hline Total & 602 & 100.0 & 148 & 100.0 & 750 & 100.0 \\
\hline
\end{tabular}

Source: Field Research, 2015

$\mathrm{X}^{2}=61.13 \mathrm{Df}=4(\mathrm{P}<0.05)=7.78$




\section{Security Organization Responsible for Safe Existence across Area Levels}

On general scale, the distribution pattern of security organizations responsible for safety as given by households revealed that Police were mostly responsible for safe existence with $33.0 \%$ of the households respond to this. While the Police took the lead, the second went to landlord/tenant vigilante (LLTV), third to no security organization, fourth to Oodua people congress (OPC), fifth to neighbourhood Police team and sixth to youth forum. From the analysis, the higher the degree of rurality the higher the increase in no organization responsible for the safety of the neighbourhood. Results showed that $22.4 \%$ and $13.2 \%$ of respondents in rural and urban settlement respectively said that no organization was responsible for the safety (Table 2). The chi-square performed across settlement types at $(\mathrm{P}<0.05)$ indicates that the difference in organisation responsible for security is significant. The implication of this is that there is a significant difference between organisation used for security by households and the settlement types in Oke-Ogun.

Table 2: Organization Responsible for Security across Settlement Types

\begin{tabular}{|c|c|c|c|c|c|c|}
\hline \multirow{3}{*}{ Organization } & \multicolumn{6}{|c|}{ Settlement } \\
\hline & \multicolumn{2}{|c|}{ Rural } & \multicolumn{2}{|c|}{ Urban } & \multicolumn{2}{|l|}{ Total } \\
\hline & Freq & $\%$ & Freq & $\%$ & Freq & $\%$ \\
\hline LLTV & 170 & 23.2 & 50 & 24.5 & 220 & 23.5 \\
\hline Police & 218 & 29.7 & 91 & 44.6 & 309 & 33.0 \\
\hline OPC & 139 & 19.0 & 36 & 17.6 & 175 & 18.7 \\
\hline NPT & 30 & 4.1 & 0 & 0 & 30 & 3.2 \\
\hline No organisation & 164 & 22.4 & 27 & 13.2 & 191 & 20.4 \\
\hline Youth forum & 12 & 1.6 & 0 & 0 & 12 & 1.3 \\
\hline Total & 733 & 100.0 & 204 & 100.0 & 937 & 100.0 \\
\hline
\end{tabular}

Source: Field Research, $2015 \quad \mathrm{X}^{2}=25.19 \mathrm{Df}=5(\mathrm{P}<0.05)=9.24$

When looking from zonal point of view in Oke-Ogun, border zone were less policed as $22.4 \%$ of the respondents in the border zone said that their areas had no security organization compared with near border zone $(19.5 \%)$ and far border zone $(20.3 \%)$. It could be adduced that the boundary of Oke-Ogun especially border zone and state boundary were porous (Table 3 )

Table 3 Security Organization Responsible for Safety across Zone Type

\begin{tabular}{|c|c|c|c|c|c|c|c|c|}
\hline \multirow{3}{*}{ Organization } & \multicolumn{8}{|c|}{ Zone Types } \\
\hline & \multicolumn{2}{|c|}{ Far Border } & \multicolumn{2}{|c|}{ Near Border } & \multicolumn{2}{|c|}{ Border } & \multicolumn{2}{|l|}{ Total } \\
\hline & Freq & $\%$ & Freq & $\%$ & Freq & $\%$ & Freq & $\%$ \\
\hline LLTV & 52 & 15.7 & 99 & 25.0 & 69 & 32.9 & 220 & 23.5 \\
\hline Police & 117 & 35.3 & 139 & 35.2 & 53 & 25.2 & 309 & 33.0 \\
\hline OPC & 75 & 22.7 & 71 & 18.0 & 29 & 13.8 & 175 & 18.7 \\
\hline NPT & 10 & 3.0 & 08 & 2.0 & 12 & 5.7 & 30 & 3.2 \\
\hline No security & 67 & 20.3 & 77 & 19.5 & 47 & 22.4 & 191 & 20.4 \\
\hline Youth forum & 10 & 3.0 & 01 & 0.3 & 0 & 0.0 & 12 & 1.3 \\
\hline Total & 331 & 100.0 & 395 & 100.0 & 210 & 100.0 & 937 & 100.0 \\
\hline
\end{tabular}

Source: Field Research, 2015

Level of Satisfaction with Crime and Security

The level of dissatisfaction with crime and security was high $(57.3 \%)$ in Oke-Ogun. The feeling of dissatisfied with crime and security was higher (Table 4$)$ in rural areas $(35.0 \%)$ than urban $(22.7 \%)$.

Table 4 Level of Satisfaction with Crime and Security

\begin{tabular}{|l|l|l|l|l|l|l|}
\hline \multirow{2}{*}{} & \multicolumn{9}{|c|}{ Settlement } & \multicolumn{2}{l|}{ Total } \\
\cline { 2 - 8 } & Rural & Urban & Freq & $\%$ & Freq & $\%$ \\
\cline { 2 - 8 } & Freq & $\%$ & 4 & 2.3 & 91 & 9.6 \\
\hline Very satisfied & 87 & 11.3 & 60 & 34.1 & 198 & 20.9 \\
\hline Satisfied & 138 & 17.9 & 40 & 22.7 & 310 & 32.7 \\
\hline Dissatisfied & 270 & 35.0 & 40 & 233 & 24.6 \\
\hline Very dissatisfied & 190 & 24.6 & 43 & 24.4 & 23 & 12.2 \\
\hline Feel no change & 87 & 11.3 & 29 & 16.5 & 116 & 100.0 \\
\hline Total & 772 & 100.0 & 176 & 100.0 & 948 & \\
\hline
\end{tabular}

Source: Field Research, $2014 \quad \mathrm{X}^{2}=39.88 \mathrm{Df}=4(\mathrm{P}<0.05)=7.78$

The high dissatisfaction level might be due to households' perception of Police patrol; because large percentage of households declared that they rarely saw the Police on patrol (Table 5). There were fewer Police officers per head in the communities who therefore had greater distances to respond to incidents. This factor 
might increase response times in some settlements that were far away from security posts and town/village centres where Police posts were located.

Table 5 Households' Frequency in Seeing Police on Patrol

\begin{tabular}{|l|l|l|l|l|l|l|}
\hline \multirow{3}{*}{ Response } & \multicolumn{7}{|c|}{ Settlement } \\
\cline { 2 - 7 } & Rural & Urban & Total \\
\cline { 2 - 7 } & Freq & $\%$ & Freq & $\%$ & Freq & $\%$ \\
\hline Very often & 72 & 9.1 & 3 & 1.6 & 75 & 7.7 \\
\hline Often & 231 & 29.2 & 27 & 42.1 & 308 & 31.6 \\
\hline Seldom & 101 & 12.8 & 36 & 19.7 & 137 & 14.1 \\
\hline Very rarely & 297 & 37.5 & 65 & 35.5 & 362 & 37.2 \\
\hline Not at all & 90 & 11.4 & 2 & 1.1 & 92 & 9.4 \\
\hline Total & 791 & 100.0 & 183 & 100.0 & 974 & 100.0 \\
\hline
\end{tabular}

Source: Field Research, $2014 \quad \mathrm{X}^{2}=40.38 \mathrm{Df}=4(\mathrm{P}<0.05)=7.78$

\section{Households' Behaviour toward Reporting Crime}

Crimes were committed at alarming rate and on daily basis in Oke-Ogun. Different types of crime were committed such as murder, armed robbery, rape, stealing to mention a few, and $69.3 \%$ of those who were victimized in one way or the other did not report to Police. Further analysis revealed that over $80 \%$ of the respondents had an awareness to report crime incidents to the Police for investigation. In spite of awareness on the part of households to report crime incident to the Police, yet many crimes committed were not reported by the victims. Unwillingness to report crime to the Police was more in the urban areas than rural areas (Table 6).

Table: 6. Victims' Behaviour towards Reporting Crime to Police

\begin{tabular}{|l|l|l|l|l|l|l|}
\hline \multirow{3}{*}{ Response } & \multicolumn{7}{|c|}{ Settlement } \\
\cline { 2 - 7 } & Rural & Urban & Total \\
\cline { 2 - 7 } & Freq & $\%$ & Freq & $\%$ & Freq & $\%$ \\
\hline Reporting & 208 & 31.9 & 27 & 23.9 & 235 & 30.7 \\
\hline Not-reporting & 445 & 68.1 & 86 & 76.1 & 531 & 69.3 \\
\hline Total & 653 & 100.0 & 113 & 100.0 & 766 & 100.0 \\
\hline
\end{tabular}

Source: Field Research, $2014 \quad \mathrm{X}^{2}=2.88 \mathrm{Df}=1(\mathrm{P}<0.05)=2.71$

These findings were not surprising considering that the degree of perceptions of susceptibility to victimization experiences drawn from oral interview were a bit lower in urban areas than rural areas. The chisquare performed across settlement types at $(\mathrm{P}<0.05)$ also indicates that the difference in distribution of victims' behaviour towards reporting crime to police was significant. Many crime committed were not reported by the victims for certain reasons which differ from crime to crime. However, the duty to report crime incidents was influenced by a number of factors drawn from respondents and some of them are considered here:

Firstly, most of the households in the study area did not know Police distress number, as more than threequarters $(75 \%)$ of the respondents in the study area (Table 7 ) affirmed that they did not know the number of Police in case of distress.

Table 7 Household's Knowledge of Police Number for Distress Call

\begin{tabular}{|l|l|l|l|l|l|l|}
\hline \multirow{2}{*}{$\begin{array}{l}\text { Have } \\
\text { knowledge }\end{array}$} & \multicolumn{6}{|c|}{ Settlement } \\
\cline { 2 - 7 } & Rural & Urban & Total \\
\cline { 2 - 7 } & Freq & $\%$ & Freq & $\%$ & Freq & $\%$ \\
\hline Yes & 169 & 24.7 & 28 & 21.5 & 197 & 24.2 \\
\hline No & 515 & 75.3 & 102 & 78.5 & 617 & 75.8 \\
\hline Total & 684 & 100.0 & 130 & 100.0 & 814 & 100.0 \\
\hline
\end{tabular}

Source: Field Research, $2014 \quad \mathrm{X}^{2}=0.6 \mathrm{Df}=1(\mathrm{P}<0.05)=2.71$

Secondly, the weight of crime event itself such as seriousness of crime, lack of evidence and inappropriateness of Police activity were said by the respondents to influence the decisions of the victims on whether or not to report the incident. In some cases, households resort to self-help measures like solve it myself, family, friends support as alternative modes of seeking redress from criminal acts inflicted.

Third, poor attitudes of the public based on experience or belief that Police is not capable of handling the matter effectively and efficiently. The sceptical attitude of residents towards Police protection also influenced non-reporting of crime. More than $41.8 \%$ of respondents said that in many reported crimes, the Police were unable to apprehend the offender, nor recover property involved or make any concrete efforts to do something else which would be beneficial for the victim. 
Households' Perception of Efficiency of Police in Apprehending Offender

About three-fifth $(59.6 \%)$ of respondents in the urban area affirmed the efficiency of Police in apprehending offenders compared to $50.0 \%$ of respondents in rural areas. It can be deduced from the observation that Police in Nigeria are not only concentrated in urban area but also more urban trained. They are poorly trained in handling special crime problems of rural areas.

Table: 8 Efficiency of Police in Apprehending Offender

\begin{tabular}{|l|l|l|l|l|l|l|}
\hline \multirow{2}{*}{ Response } & \multicolumn{7}{|c|}{ Settlement } \\
\cline { 2 - 7 } & Rural & Urban & Total \\
\cline { 2 - 7 } & Freq & $\%$ & Freq & $\%$ & Freq & $\%$ \\
\hline Very efficient & 97 & 12.4 & 9 & 4.8 & 106 & 10.9 \\
\hline Efficient & 295 & 37.6 & 103 & 54.8 & 398 & 40.9 \\
\hline Inefficient & 275 & 35.1 & 50 & 26.6 & 325 & 33.4 \\
\hline Very inefficient & 117 & 14.9 & 26 & 13.8 & 143 & 14.7 \\
\hline Total & 784 & 100.0 & 188 & 100.0 & 972 & 100.0 \\
\hline
\end{tabular}

Source: Field Research, $2014 \quad \mathrm{X}^{2}=22.28, \mathrm{Df}=3(\mathrm{P}<0.05)=6.25$

The chi-square performed across settlement types at $(\mathrm{P}<0.05)$ indicates that the difference in efficiency of police in apprehending offender is significant. The implication of this is that there was a significant difference between perception of efficiency of police in apprehending offender by households and the settlement types in Oke-Ogun.

Households' Perception of Adequacy of Policing

At aggregation level, 52\% of all respondents in Oke-Ogun agreed with the adequacy of policing out of which $13.6 \%$ said that the policing was very adequate and $38.4 \%$ said that it was only adequate while $48 \%$ of all respondents were at variance with the adequacy of policing.

Table: 9 Respondents Perception of Adequacy of Policing

\begin{tabular}{|l|l|l|l|l|l|l|}
\hline \multirow{2}{*}{ Response } & \multicolumn{7}{|c|}{ Settlement } \\
\cline { 2 - 7 } & Rural & Urban & Total \\
\cline { 2 - 7 } & Freq & $\%$ & Freq & $\%$ & Freq & $\%$ \\
\hline Very adequate & 129 & 16 & 8 & 0.40 & 137 & 13.6 \\
\hline Adequate & 282 & 34.9 & 104 & 52.0 & 386 & 38.4 \\
\hline Inadequate & 233 & 28.9 & 66 & 33.0 & 299 & 29.7 \\
\hline Very inadequate & 162 & 20.1 & 22 & 11.0 & 184 & 18.3 \\
\hline Total & 806 & 100.0 & 200 & 100.0 & 1006 & 100.0 \\
\hline
\end{tabular}

Source: Field Research, $2014 \quad \mathrm{X}^{2}=0.937 \mathrm{Df}=3(\mathrm{P}<0.05)=6.25$

The households $(49.0 \%)$ in the rural areas were cynical about adequacy of policing, while out of $49.0 \%$, $28.9 \%$ said that policing was inadequate and $20.1 \%$ said that policing was very inadequate. The chi-square performed across settlement types at $(\mathrm{P}<0.05)$ indicates that the difference in adequacy of policing was significant. The implication of this is that there is a significant difference between perception of adequacy of policing by households and the settlement types in Oke-Ogun (Table 9).

Households also held view that Police in Oke-Ogun did not give a prompt response expected in situations of distress call. Response to unwillingness to give prompt response to distress call by Police was on top gear in rural settlements. About $39 \%$ of all respondents in rural areas said that Police gave prompt response needed to distress call compared to $41.7 \%$ in -urban areas of Oke-Ogun (Table 10).

Table: 10 Perception of Police Response to Distress Call

\begin{tabular}{|l|l|l|l|l|l|l|}
\hline \multirow{2}{*}{ Response } & \multicolumn{7}{|c|}{ Settlement } \\
\cline { 2 - 8 } & Rural & Urban & Total \\
\cline { 2 - 8 } & Freq & $\%$ & Freq & $\%$ & Freq & $\%$ \\
\hline Promptly & 293 & 38.7 & 68 & 41.7 & 361 & 39.2 \\
\hline Reluctantly & 361 & 47.7 & 89 & 54.6 & 450 & 48.9 \\
\hline Not at all & 103 & 13.6 & 6 & 3.7 & 109 & 11.8 \\
\hline Total & 757 & 100.0 & 163 & 100.0 & 920 & 100.0 \\
\hline
\end{tabular}

Source: Field Research, $2014 \quad \mathrm{X}^{2}=12.77 \mathrm{Df}=2(\mathrm{P}<0.05)=4.80$

From every indication in Oke-Ogun rural areas, policing was said to be both inadequate and inefficient (Table $9 \& 10$ ). The households of Oke-Ogun in general were at best cynical about Police protection. Households have reacted that Police in Oke-Ogun extremely accept a case when it is reported to it. Noteworthy exception to normal Police performance are to be in cases of political 'violence' (as defined by government) cases in which 'first class' citizens and high government officials are victims, or those that involve homicide. 
The general public feel that Police in Oke-Ogun lacks not only essential human and material investigative and detective resources but also unwillingness to do the job.

\section{Households' Preference for Security Organization across spatial levels}

The analysis of respondents' preference for security group in Oke-Ogun revealed that majority of households $38.2 \%$ preferred neighbourhood policing team above every other organization, though the organization was very rare in every neighbourhood across settlement and zone types (Table 11). The chi-square performed across settlement types at $(\mathrm{P}<0.05)$ indicates that the difference in households' preference for security organisation is significant. The implication of this is that there was a significant difference between preference for security organisation by households and the settlement types in Oke-Ogun.

Table 11 Households' Preference for Security Group across Settlements

\begin{tabular}{|l|l|l|l|l|l|l|}
\hline \multirow{2}{*}{ Choice } & \multicolumn{6}{|c|}{ Settlement } \\
\cline { 2 - 7 } & Rural & Urban & Total \\
\cline { 2 - 7 } & Freq & $\%$ & Freq & $\%$ & Freq & $\%$ \\
\hline Police & 181 & 22.9 & 54 & 29.7 & 235 & 23.8 \\
\hline NPT & 301 & 38.0 & 76 & 39.0 & 377 & 38.2 \\
\hline OPC & 240 & 30.3 & 52 & 26.6 & 292 & 29.6 \\
\hline LLTV & 50 & 06.3 & 13 & 6.7 & 63 & 6.4 \\
\hline Youth forum & 20 & 02.5 & 0 & 0.0 & 20 & 2.0 \\
\hline Total & 792 & 100.0 & 195 & 100.0 & 987 & 100.0 \\
\hline
\end{tabular}

Source: Field Research, $2015 \quad \mathrm{X}^{2}=39.98 \mathrm{Df}=4(\mathrm{P}<0.05)=7.78$

Neighbourhood Policing Team (NPT) is referred to security support provided by teams of Police officers and local authority wardens, often together with volunteer and partners. Neighbourhood policing teams (NPT) aims at providing people who live and work in a neighbourhood be it rural, peri-urban urban or otherwise with:

(i) access to local planning policing services through a named point of contact

(ii) influence over policing priorities in their neighbourhood

(iii) intervention through joint action with partners and the public and

(iv) sustainable solutions and feedback on what is being done.

Households felt that the neighbourhood policing teams took much more-time than any other security organization to find out what local issues were, and gave the issues immediate attention they deserve in order of priority. They also remarked that neighbourhood policing team were easy to get in contact with. OPC was ranked second, followed by Police then landlord/tenant vigilante (LLTV) group then followed by youth forum. But if we are to consider the distribution pattern at spatially disaggregated levels especially on settlement basis, the pattern is a bit different. All settlement types but urban settlement had the same pattern as observed for OkeOgun area at aggregated level. After neighbourhood policing team (NPT), the urban households preferred Police to Oodua people congress (OPC)

On zonal levels, the analysis showed that OPC was mostly preferred in border and near border zones after NPT to other security organization (Table 5). It could be adduced here that majority of urban settlements especially in far border zones preferred Police to Oodua people congress (OPC). The town in far border zone include Igbeti, Igboho and Kishi.

Table 12 Households' Preference for Security Group across Zone Types

\begin{tabular}{|c|c|c|c|c|c|c|c|c|}
\hline \multirow[b]{3}{*}{ Choice } & \multicolumn{8}{|c|}{ Zone Types \% } \\
\hline & \multicolumn{2}{|c|}{ Border } & \multicolumn{2}{|c|}{ Near Border } & \multicolumn{2}{|c|}{ Far Border } & \multicolumn{2}{|c|}{ Total } \\
\hline & Freq & $\%$ & Freq & $\%$ & Freq & $\%$ & Freq & $\%$ \\
\hline Police & 62 & 20.7 & 111 & 27.6 & 62 & 21.5 & 235 & 23.8 \\
\hline NPT & 95 & 31.8 & 129 & 32.3 & 153 & 53.1 & 377 & 38.2 \\
\hline OPC & 98 & 32.8 & 138 & 34.5 & 561 & 19.4 & 292 & 29.6 \\
\hline LLTV & 31 & 10.4 & 17 & 4.3 & 15 & 5.3 & 63 & 6.4 \\
\hline Youth forum & 13 & 4.3 & 5 & 1.3 & 2 & 0.7 & 20 & 2.0 \\
\hline Total & 299 & 100.0 & 400 & 100.0 & 288 & 100.0 & 987 & 100.0 \\
\hline
\end{tabular}

Source: Field Research, $2015 \quad \mathrm{X}^{2}=44.91 \mathrm{Df}=8(\mathrm{P}<0.05)=13.36$

The choice in far border zone was not surprising as the settlements in the zone were highly noted for breach of public peace which wass political in nature. The households reacted that OPC members were mostly used to fuel the crisis, crisis in which first class citizen (e.g. king, chief) and high government officials were victims. The households in far border zone reacted that OPC were extremists in dealing with issues as they were being intoxicated by their ability to use African protective and magical devices.

Here are the reasons given by the households on each security used:

Oodua people congress (OPC) was the second most preferred security organization after Neighbourhood 
policing team (NPT) across settlements. This group was preferred because of the ability of the members to use African protective and magical devices with consistently commendable accuracy, and also their ability to render instant justice to criminals. To majority of households, the members were seen as reliable and honest. Their transparency in dealing with issues was generally thought to be attached to strong covenant forged among the members. The covenant that bonds them together was said to be difficult for any member to break without experiencing unpleasant consequences.

Police: This is the third preferred security group. The choice of this group was attributed to the confidence reposed in their weapons, training and legal status being the organization charged with security of lives and properties in the nation.

Landlord/Tenant Vigilante: LLTV was the fourth preferred security group. Among the reasons provided by households in support of LLTV group include the fact the LLTV groups were constituted by the landlord (property owners) and tenants of each neighbourhood which afford them the opportunity of knowing the problem of the people enough to provide the immediate attentions as deserved. Other desirable characteristics as pointed out by households included the ability of LLTV group to recognize stranger easily, closeness to households, availability and prompt response to distress call. They were also seen as reasonable in the judgement as well as approachable. The last is the youth forum; this group to come by in every settlement type was as rare as neighbourhood Police team. Youth forum was said to be a last resort that takes over in critical situations

\section{Households' Preference for Means of Keeping Neighbourhood Safe}

There was a difference among settlement types in their preference for means of keeping their neighbourhood safe but the difference not much considerable. The chi-square analysis performed $(\mathrm{P}<0.05)$ indicated that the difference in households preference for means of keeping neighbourhood safe across settlement types was significant at 0.05 level of significance. Calculated $\mathrm{X}^{2}$ - value is 21.03 and the critical (table) value is 10.64.

Across settlement types, provision of job for the unemployed is mostly preferred. Over half $(50.3 \%)$ of the respondents in urban settlements of Oke-Ogun preferred job provision, to every other option, for the unemployed persons. This is portentous reflexion of palpable unemployment and a high rate of joblessness in urban settlements in Oke-Ogun.

Residents in Oke-Ogun especially in the urban areas reacted that nothing had more caused crime than unemployment. They further argued that before the coming of the white-men to Nigeria our forefathers had learnt to work with their hands. Also, they never encouraged any habits of laziness in their children, wives and slaves. But when civilization came children were sent to school in great numbers, and when they were out of school they worked for the whitish either in offices or as interpreters especially for missionary teachers, traders, preachers and crusaders. Nowadays, no plan for the turn-outs from school and many of the school leavers outnumber the opportunity for employment. So, the problem of unemployment is becoming more and more acute. Therefore, residents in Oke-Ogun believed that the failure of young school leavers to enter and remain in the labour market has a negative impact not only on their desire to conform to social norms but also on their participation in a stable life style. These unemployed youth feel there was no past to succour and also feel that the present and future are denied then and they could only survive by engaging themselves in criminal acts.

The next preferred means was imposition of fine on offender. Residents in Oke-Ogun stressed that fine should be exorbitant such that it should be six times higher than the monthly income of offenders and it should be according to the income status of the offender.

Jailing of offenders was ranked third in respondents' preference for making Oke-Ogun safer. Jailing of offender was highly supported and there was a public clamour for establishing branch of Nigerian prison by the public who liked the feeling of greater security that prison gives. Residents also believed that preventive imprisonment dealt effectively with the main offenders (Table 7.16 for disaggregate analysis of residents' response across the localities, to means of making Oke-Ogun safer). In reality, the real criminals often escape the net and the end result is a set of measures aim at intimidating that sector of the population which is prone to criminality. 
Table 13: Households' Preference for Keeping Neighbourhood Safe

\begin{tabular}{|l|l|l|l|l|l|l|}
\hline \multirow{2}{*}{ OPTION } & \multicolumn{9}{|c|}{ Settlement } \\
\cline { 2 - 7 } & Rural & Urban & \multicolumn{2}{l|}{ Total } \\
\cline { 2 - 7 } & Freq & $\%$ & Freq & $\%$ & Freq & $\%$ \\
\hline Job provision for unemployed & 197 & 25.9 & 88 & 50.3 & 285 & 29.8 \\
\hline Imposition of fine on offender & 143 & 18.9 & 22 & 12.6 & 187 & 19.6 \\
\hline Jailing of offender & 148 & 19.5 & 27 & 15.4 & 175 & 18.3 \\
\hline Counselling of offender & 52 & 6.9 & 0.0 & 0.0 & 52 & 5.4 \\
\hline Equip vigilante group & 112 & 14.8 & 26 & 14.9 & 138 & 14.5 \\
\hline Community mobilization & 55 & 7.3 & 3 & 1.7 & 58 & 6.1 \\
\hline Improved infrastructure & 51 & 6.7 & 9 & 5.1 & 60 & 63 \\
\hline Total & 758 & 100.0 & 175 & 100.0 & 955 & 100.0 \\
\hline
\end{tabular}

Source: Field Research, 2015

$\mathrm{X}^{2}=21.03, \mathrm{Df}=6(\mathrm{P}<0.05)=10.64$

Equip vigilant groups was ranked fourth. The residents therefore stressed that in many occasions, the weapons of criminals were more sophisticated than vigilant groups. However, residents felt that equipping vigilant groups would enhance the group's effectiveness in curbing crime. Improved infrastructure was ranked fifth. Respondents stressed that if infrastructure were improved, there would be more days for employments. They further argued that the collapsing of our infrastructures in Nigeria has a great negative impact not only on economy but also on every sphere of social values and norms

There was a difference among settlement types in their preference for means of keeping their neighbourhood safe but the difference was not much considerable. The chi-square analysis performed $(\mathrm{P}<0.05)$ indicates that the difference in households' preference for means of keeping neighbourhood safe across settlement type is significance.

\section{The Police View and Crime Prevention}

The Police authority in Oke-Ogun area vehemently expressed a long - held view by the citizens that the Police must shoulder responsibility of crime prevention as obsolete. The Police arguably emphasized that policing for crime prevention was neither recent nor alien to Nigerian society, therefore crime prevention should be a fundamentally community - wide responsibility and the Police could no longer be expected to control and prevent crime without the active support of the wider community. Police emphasized further that the average citizens saw them as task masters, and a were at best cynical about Police protection; as a result they could not enjoy the degree of confidence and amount of cooperation it should enjoy from average citizens for effective crime management.

Police authority supported its arguments that a desire to have 24 hours security presence for residence and organization could not be met as Police authority in Oke-Ogun did not have enough human resources and sophisticated material resources and time to provide one particular business or neighbourhood. It also buttressed the argument that there was no direct relationship between Police recruitment and population growth and the rapid population growth made the population ratio to be on the rise, thus reducing the chances of a quick response expected by the citizens in situation of distress call.

\section{Planning Implications / Policy Oriented Remarks}

Urban and Regional planning is a response to the phenomena of environmental problems. It therefore not only makes use of its instruments (e.g. development control) to deals with the ordering of land uses according to laid down principles, but also provides superior decision support for policy makers in resource allocation decisions for the purpose of creating a conducive atmosphere for living, working and recreating. From findings, response to unwillingness to give prompt response to distress call by Police was on top gear in rural settlements and households held view that Police in Oke-Ogun did not give a prompt response expected in situations of distress call. A long-standing global ideal is that rural places are crime-free to live, and that crime is by no means nonexistent in the countryside (Yarwood, 2007). This perception is not accurate, but made up of exaggerations of reality that contain elements of the truth. Yet, relative to the problems of some large urban communities, there is every tendency to assume that villages and rural towns that make up a region in developing and less developed countries are havens of safety and paradise of tranquillity. Noteworthy to say, countryside today might be suggested to have less crime than its urban counterpart does, but it should be understood that countryside might have more crime than it did in the past, and its crime level might be equally serious. It is evident that rural environment is distinct from urban environment in ways that affect policing, crime and public policy, but neglecting rural security is justifiable if there is nothing about crime, or the rural area that precludes directly applying knowledge from urban area. In essence, a sustainable policy is that which is aimed at providing just and fair judgement by avoiding double standard in the administration of justice and equal opportunities in allocation 
of security resources for urban and rural areas by providing adequate access to basic security amenities. Apparently, these would help partly to reduce the volume of crime occurrences in general and partly to redistribute criminal activities spatially. The argument being that as far as no area has more than its share of criminality, all things being be equal, no area would have more than its share of criminality and no problem area would become incurable and pervasive in its effect if attacked at the present time.

\section{REFERENCES}

Adeagbo, D. (2001) "Security of Lives and Property in the Peri-Urban: An Assessment of the Efforts of Landlords/Tenants Associations." Paper presented at the International Conference on Security, Segregation and Social Networks in West Africa Cities $19^{\text {th }}-20^{\text {th }}$ centuries, held at the International Centre for African Studies (IFRA) University of Ibadan, $29^{\text {th }}-31^{\text {st }}$ October, 2001

Adejumobi, C.A. Oni, N.O. and Ige, J.O. (2009) "Crime Occurrence and Community Policing in Southwestern Nigeria". Journal of Social Policy and Society. Vol 4, No 1, pp 112-119

Agbola, T. (1997) Architecture of fear, Urban Design and Construction. Response to Urban Violence in Lagos, Nigeria. Ibadan. IFRA

Agnew, R. (1999) “A General Strain Theory of Community Differences in Crime Rates.” Journal of Research in Crime and Delinquency, Vol. 36, pp.123-155

Aguda, A.S (1994) “Areal and Ecological Analysis of Crime: A Case Study of a Nigerian City”. In Albert, I.O, Adisa, J. Agbola, T. and Herualt, G (Eds) Urban Management and Urban Violence in Africa. Vol $1 \mathrm{pp}$ 1-8. Ibadan: IFRA

Albert, I.O. (1994) "Urban violence in Contemporary Africa: Some Theoretical Exploration”. In Albert, I.O, Adisa J., Agbola T. and Herault, G. (Eds) Urban Management and Urban Violence in Africa. Vol 1 pp 920. Ibadan IFRA

Akinrinde, S. (2007) "Menace of Bandits”, Newswatch Magazine, April 22, Lagos: Newswatch Communication Limited.

Alemika, E.E.O. (2006) "Crime Statistics and Information Management in Nigerian Justice and Security Systems". In Alemika, E.E.O. and Chukwuma, I. (Eds). Crime and Policing in Nigeria: Lagos, Nigeria, Centre for Law Enforcement Education.

Ayeni-Akeke, A. (2001) "Collective Violence and Insecurity in Nigeria cities: Some Theoretical Consideration". Paper Presented at the International Conference on Security Segregation and Social Network in West Africa Cities $19^{\text {th }}-20^{\text {th }}$ centuries held at the International Centre for African Studies (IFRA) University of Ibadan Oct $29^{\text {th }}-31^{\text {st }}, 2001$.

Felson, M. (1998) "\{Crime and Everyday Life": $2^{\text {nd }}$ Ed, Pine Forge Press, Thousand Oaks.

Friendmann, J. (1966) Regional Development Policy: A Case Study of Venezuela, Cambridge, Massachusetts: The John Hopkins Press.

Friedman, W. (1995). Research, organizing and the campaign for community policing in Chicago. In Nyden et al. (Eds.), The Collaborative Community: New models for social research. Thousand Oaks, CA: Pine Forge Press.

Greene, J.R and Mastrofski, S.D. (Eds.) (1988) Community policing: Rhetoric or reality. New York: Praeger

Mawby, R.I. (2006) "Crime, Place and Explaining Rural Hotspots". Paper presented at the Crime in Rural Communities Conference, Rural Crime Centre, University of New England, Armidable, New South Wales, online

Mawby, R. I. (2004). "Myth and reality in rural policing: Perceptions of the Police in a rural county of England. Policing": An International Journal of Police Strategies and Management, Vol. 27 No 3: pp 431-446

Obateru, O.I (1994) "Planning the City to Mitigate Urban Violence". In Albert, O.I, Adisa J., Agbola,T. and Herault, G. (Eds) Urban Management and Urban Violence in Africa.Vol. 1. Ibadan: IFRA

Obudho, R.A. and Owuor, S.O. (1994) Urbanization and Crime in Kenya. In Albert, I.O.,Adisa, J., Agboola, T. and Hearault, G. (Eds) Urban Management and Urban Violence in Africa. Vol.1 pp 41-42 Ibadan: IFRA.

Odekunle, F. (1982) "Crime and Social Defence", in Akeredolu, A. (Ed.) Social Development in Nigeria: A Survey of Policy Research. Oxford University Press, Ibadan. Pp $67-92$

Okunola, R. A. (2002) "Crime in Society: Current and Perspective" in Uche Abanihe, Austin Isamah and Jimi Adesina (Eds) Current and Perspective in Sociology, Lagos: Malthouse Press Ltd, pp349-366

Omisakin, I.S. (1998) “Crime Trends and Prevention Strategy in Nigeria”. A study of Old Oyo State": NISER Monograph pp1-7.

Onyeozili, E. C. (2008) "Obstacles to Effective Law Enforcement in Nigeria”, African Journal of Criminology and Justice Studies, Vol. 1, No. pp11-23

Rosenbaum, D.P. (1987). "The theory and research behind neighborhood watch: Is it a sound fear and crime reduction strategy?" Crime and Delinquency, Vol. 33No 1, pp 90 - 102.

Rosenbaum, D.P. Lurigio, J. (1994) “An Inside Look at Community Policing Reform: Definitions, 
Organizational Changes, and Evaluation Findings. Crime and Delinquency, Vol. 40 No 3, pp 299-314.

Shaftoe, H. (2002) "Social Crime Preventions to Reduce the Motivation to Offend". Synopsis of Presentation at Tallinn City Council $15^{\text {th }}$ April.

Skogan, W., and Hartnett, S. (1997). Community policing: Chicago style. New York: Oxford University

Yarwood, R. . (2007). "Getting just Deserts? Policing, Governance and Rurality in Western Australia. Geoforum, Vol 38 No 2, pp 339-352 